\title{
INVESTIGAÇÃo PETROLÓGICA E GEOQUÍMICA DE ROCHAS ALCALINAS
}

C.B.Gomes ${ }^{1}$

E.Ruberti ${ }^{1}$

O magmatismo alcalino, que se manifesta em numerosos focos distribuídos pelo território continental brasileiro, ainda que concentrados principalmente junto às porções marginais da Bacia do Paraná, apresenta características gerais que fazem dele tema da maior relevância: 1) número elevado de ocorrências (superior a 100), 2) área de exposição dos corpos se estendendo de poucos metros quadrados a centenas de quilômetros quadrados (Poços de Caldas, > $800 \mathrm{~km}^{2}$ ), 3) grande heterogeneidade textural como resultado de modos de ocorrência os mais diversos, reunindo desde formas plutônicas, hipoabissais a vulcânicas, 4) ampla variação do ponto de vista mineralógico, petrográfico e químico, 5) largo espectro cronológico, precambriano ao terciário, não obstante a maior concentração de idades se dê no Cretáceo Inferior, 6) enorme importância econômica, uma vez que se constitui em fontes várias, em processo de exploração, de recursos minerais como nióbio, fosfatos, titânio, bauxita, urânio, vermiculita etc.

O tema adquire maior interesse considerando que, junto à borda ocidental da Bacia, em território paraguaio, são conhecidas outras dezenas de ocorrências, guardando as mesmas características gerais, e, a exemplo também das congêneres brasileiras, ainda no todo pouco conhecidas quanto aos seus principais aspectos geológicos, mineralógicos, petrológicos, geoquímicos e geocronológicos.

À vista da insuficiência de dados e da grande abrangência do assunto, é que se deu início, em 1985, a um programa de investigação sistemática das rochas brasileiras e, a partir de 1987, também das paraguaias, envolvendo grande número de pesquisadores, de forma a se obter, no menor tempo possível, uma visão mais abrangente dos aspectos acima apontados.

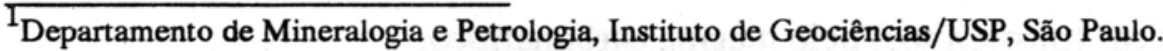


Além de docentes, estudantes de pós-graduação e de graduação do Instituto de Geociências, ele vem contando ainda com a participação de pesquisadores de outras instituições universitárias do país e do exterior, notadamente da Itália.

Presentemente, as atividades de pesquisa oferecem o seguinte quadro: Brasil - trabalhos concluídos (artigos devidamente publicados, no prelo ou submetidos) nas ocorrências alcalinas de Anitápolis, Banhadão, Fortaleza, Ilha de Vitória, Juquiá, Morro Redondo, Piratini e Tunas; em andamento nas de Barra do Itapirapã, Jacupiranga, Lages, Mato Preto e Passa Quatro, bem como no maciço de Tunas quanto aos aspectos geológicos e petrograficos das brechas; em fase inicial nos complexos carbonatíticos do Alto Paranaíba (Araxá, Catalão I-II, Salitre I-II, Serra Negra, Tapira) e Ipanema; Paraguai - atividades de pesquisa focalizando as diversas ocorrências da Província Central, com os trabalhos encerrados por ora apenas em Acahay e Sapucai (diques).

Conquanto seja prematura qualquer tentativa de interpretar-se o magmatismo alcalino como um todo, com vistas ao fornecimento de respostas para muitas questões colocadas, as informações disponíveis permitem, no entanto, que já sejam feitas algumas considerações preliminares de ordem geral para os complexos mesozóicos a terciários brasileiros:

1. dados geoquímicos disponíveis apontam para a existência de uma província de caráter potássico, reunindo principalmente os diversos maciços pertencentes à Província da Serra do Mar; por sua vez, as ocorrências associadas com carbonatitos tendem a exibir natureza caracteristicamente mais sódica;

2. cálculos de balanço de massa, aliados a evidências mineralógicas, texturais e geoquímicas, indicam que cristalização fracionada foi um processo determinante na formação das rochas de alguns complexos, bem como que o seu magma parental muito possivelmente seria de afinidade basanítica;

3. dados isotópicos para a razão inicial $\mathrm{Sr}^{87} / \mathrm{Sr}^{86}$, excluída a província terciária de Fortaleza $\left(R_{0}=0,7024-0,7057\right.$; inferido para o material mais primitivo 0,7029 0,7036), acham-se compreendidos no intertervalo 0,7046-0,7081 (Juquiá, 0,7052-0,7080; Lages, 0,7052-0,7078; Morro Redondo, 0,7049-0,7056; Piratini, 0,7046-0,7057; Tunas, 0,7046-0,7081), sendo, assim, consistentes com uma derivação mantélica para o magma parental dessas rochas, com os valores mais altos podendo representar alguma contaminação crustal;

4. glimmeritização é um processo comum à totalidade dos complexos carbonatíticos conhecidos, estando a sua origem ligada à alteração metassomática (fenitização interna) de rochas ultrabásicas (piroxenitos) pelo magma carbonatítico; 
5. a despeito da dispersão de alguns valores, a análise crítica dos dados radiométricos $\mathrm{K} / \mathrm{Ar}$ e $\mathrm{Rb} / \mathrm{Sr}$ (novos e antigos) e de traços de fissão em apatita disponíveis aponta, cada vez mais, para o caráter bimodal do magmatismo (não incluídas as ocorrências precambrianas e terciárias), com os picos dessa atividade em torno de 80 e $130 \mathrm{Ma}$.

Quanto aos complexos paraguaios, são ainda mais difíceis as generalizaçōes, uma vez que apenas as ocorrências da Província Central, ao que tudo faz crer desprovidas de carbonatitos, vêm sendo investigadas de forma sistemática. As poucas informações disponíveis possibilitam concluir que:

1. A Província Central como um todo parece ser de natureza tipicamente potássica;

2. valores para $\mathrm{Sr}^{87} / \mathrm{Sr}^{86}$, à exceção dos relativos aos nefelinitos terciários das imediaçōes de Assunção $\left(R_{0}=0,7036-0,7039\right)$, situam-se ao redor de 0,7073;

3. aparentemente, as rochas dessa província têm a sua origem ligada a um único evento de formação, o de $130 \mathrm{Ma}$. 